\title{
Dispnea After Appendectomy Operation: Case Report
}

\author{
Apendektomi Operasyonu Sonrası Dispne: Olgu Sunumu \\ Zeliha ARSLAN, ${ }^{1}$ Mithat BIYIKLI, ${ }^{2}$ Kürşat YILDIZ, ${ }^{3}$ Berrin ÇETINARSLAN, ${ }^{2}$ Ahmet ILGAZLI ${ }^{1}$ \\ Departments of ${ }^{1}$ Chest Diseases, ${ }^{2}$ Endocrinology and Metabolism, ${ }^{3}$ Pathology, Medical Faculty of Kocaeli University, Kocaeli
}

Submitted / Başvuru tarihi: 27.07.2008 Accepted / Kabul tarihi: 19.10.2008

\begin{abstract}
Pulmonary Langerhans cell histiocytosis (PLCH) is a rare interstitial lung disease. Its estimated prevalence is two to five cases per million. Young male adults develop the disease most frequently. Greater than $90 \%$ of cases of PLCH occur in smokers. Diabetes insipidus (DI) occurs in about $11 \%$ to $40 \%$ of patients and pneumothoraces occur in $10 \%$ to $30 \%$ of patients. The diagnosis of $\mathrm{PLCH}$ can be confirmed by BAL, transbronchial biopsy, or surgical lung biopsy. We present a case referred to us with dispnea developed after appendectomy operation, coexisting with $\mathrm{DI}$, and diagnosed to have PLCH using transbronchial lung biopsy.

Key words: Pulmonary Langerhans cell histiocytosis (PLCH); interstitial lung disease; diabetes insipidus; transbronchial lung biopsy; dispnea.
\end{abstract}

Pulmoner Langerhans hücreli histiyositoz $(\mathrm{PLCH})$ nadir görülen bir interstisyel akciğer hastalığıdır. Tahmini prevalansı milyonda iki ila beş arasında olup özellikle genç erkeklerde görülür. Olguların \%90'ından fazlası sigara içenlerde görülür. \%10-\%40'ında diabetes insipidus eşlik eder ve \%10-\%30'unda pnömotoraks görülebilir. Tanı BAL, transbronşiyal biyopsi veya açık akciğer biyopsisi ile konur. Apandektomi operasyonu sonrası gelişen dispne şikayeti ile başvuran, diabetes insipidusun eşlik ettiği ve transbronşiyal akciğer biyopsisi ile PLCH tanısı alan olguyu sunuyoruz.

Anahtar sözcükler: Pulmoner Langerhans hücreli histiyositoz; intertisyel akciğer hastalığı; diabetes insipidus; transbronşiyal akciğer biyopisi; dispne.
Pulmonary Langerhans cell histiocytosis (PLCH) is a rare interstitial lung disease. Young male adults develop the disease most frequently. Greater than $90 \%$ of cases of PLCH occur in smokers. Diabetes insipidus (DI) occurs in about $11 \%$ to $40 \%$ of patients and pneumothoraces occur in $10 \%$ to $30 \%$ of patients. The diagnosis of PLCH can be confirmed by BAL, transbronchial biopsy, or surgical lung biopsy.

\section{CASE REPORT}

A 19-year-old male presented with a four-week history of dyspnea and hemoptysis which had begun after the appendectomy operation, which was performed in emergency conditions, and worsened with time. Previous medical details were not remarkable except for a history of frequent thirst and excessive urine volume. He had also a smoking history of 1 pack/ year. Physical examination revealed that the patient was tachypneic, but not in respiratory distress, with a respiratory rate of 32 breaths per min. He had no cyanosis and edema. There were erythematous papular skin lesions at axilla, postauricula and scalp. On auscultation rales were present bilaterally at the mid and lower zones of the lungs. Chest radiography revealed diffuse micronodular and interstitial-appearing infiltrates and small cystic air spaces (Fig. 1). High resolution computed tomography (HRCT) scan showed bilaterally uniform thin-walled cysts of $1-1.5 \mathrm{~cm}$ in diameter suggesting PLCH and Lymphangiomyomatosis (Fig. 2).

Correspondence (illetişim adresi): Dr. Zeliha Arslan. Kocaeli Üniversitesi Tıp Fakültesi Göğüs Hastalıkları Anabilim Dalı, 41380 Edirne. Tel: 0262 - 3037215 Fax (Faks): 0262 - 3037001 e-mail (e-posta): zelihaar@yahoo.com

(c) Trakya Üniversitesi Tıp Fakültesi Dergisi. Ekin Tıbbi Yayıncıık tarafından basılımıstır. Her hakkı sakıdır.

(c) Medical Journal of Trakya University. Published by Ekin Medical Publishing. All rights reserved. 


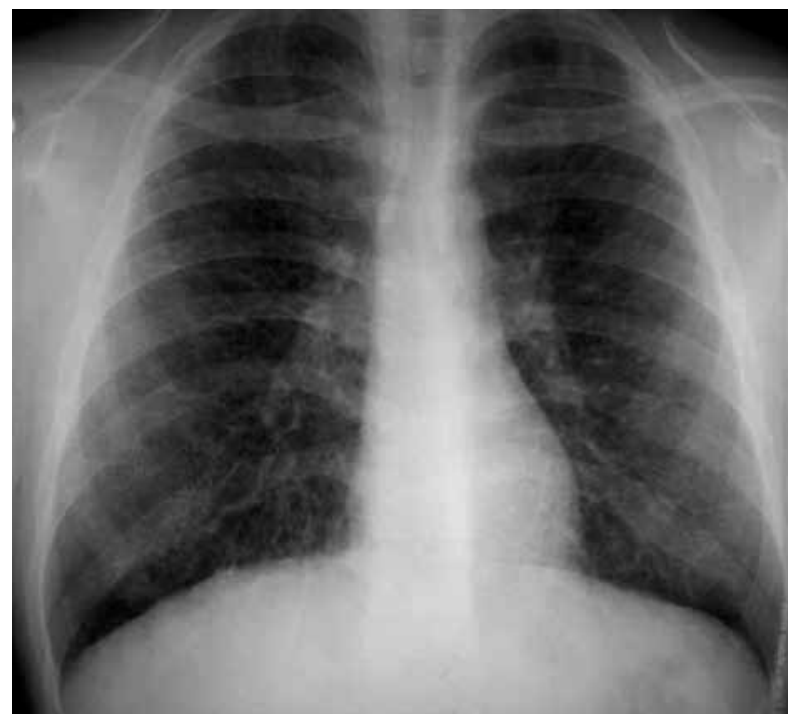

Fig. 1. Chest radiography: Diffuse micronodular and interstitialappearing infiltrates and small cystic air spaces.

The patient was intended to be prepared for fiberoptic bronchoscopy but the task could not be achieved because he was unable to stay at least three hours without drinking water. Endocrinology Department was asked for a magnetic resonance imaging of hypophysis which did not show T1 intensity of neurohypophysis that is normally located on the posterior of hypophysis. Fluid deprivation test and desmopressin stimulation test were performed. The patient responded with decreased urine output and increased urine osmolality. Pituitary hormones were normal. He was diagnosed to have central diabetes insipidus and his treatment with vasopressin was started. While waiting for the results of the tests, the patient developed acute right-sided chest pain requiring urgent evaluation. Physical examination revealed tachypnea and decreased respiratory sounds over the right side of the lung. He had a right-sided spontaneous pneumothorax. After insertion of the chest

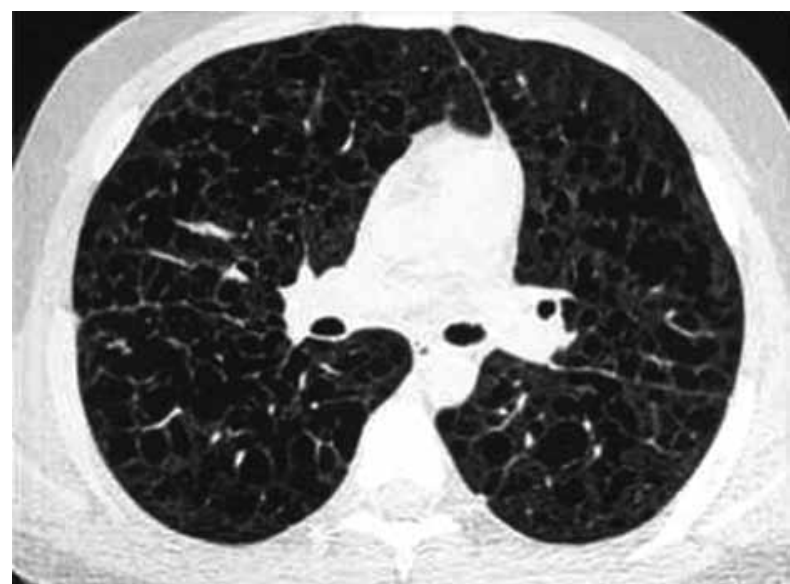

Fig. 2. High resolution computed tomography scan showing bilaterally uniform thin-walled cysts $1-1.5 \mathrm{~cm}$ in diameter. tube, his symptoms regressed. Bronchoscopic transbronchial lung biopsy and bronchoalveolar lavage were performed.

Although bronchoalveolar lavage was not diagnostic, histopathological examination was suggesting PLCH. Microscopic evaluation showed diffuse histiocytic infiltrations at pulmonary parenchyma around the bronchi. Eosinophils were remarkable through the histiocytes. Immunohistochemical tests were performed. CD1a and S-100 showed strong reactions with histiocytes (Fig. 3). The patient was diagnosed to have PLCH coexisting with DI.

\section{DISCUSSION}

Pulmonary Langerhans cell histiocytosis is a rare interstitial lung disease. Eosinophilic granuloma, histiocytosis $\mathrm{X}$ are used as synonyms. Mostly, it is a multifocal disease involving bones of the skull, extremities, ribs, pelvis, vertebrae, and mandible with lytic lesions. The triad of lytic skull lesions, exophthalmus, and pituitary involvement producing diabetes insipidus is known as Hand-Schuller-Christian disease. A diffuse form of histiocytosis of the Letterer-Siwe type is a fulminant disease generally unresponsive to therapy. ${ }^{[1]}$

The Langerhans cell is an antigen-presenting cell that is derived from the monocyte-macrophage cell line. Actually, Langerhans cells are commonly found in healthy lung tissue. In patients with PLCH, these cells proliferate and accumulate to form pathologic nodules. Systemic disease can occur, and usually involves the bone, skin, pituitary, thyroid, liver, and lymph nodes. ${ }^{[2]}$

Estimated prevalence of histiocytosis $X$ is two to five cases per million. It can affect all ages, but young adults, especially men, as was the case for this patient, develop the disease most frequently.

Symptoms may have an insidious onset, with cough and breathlessness with exertion as initial complaints.

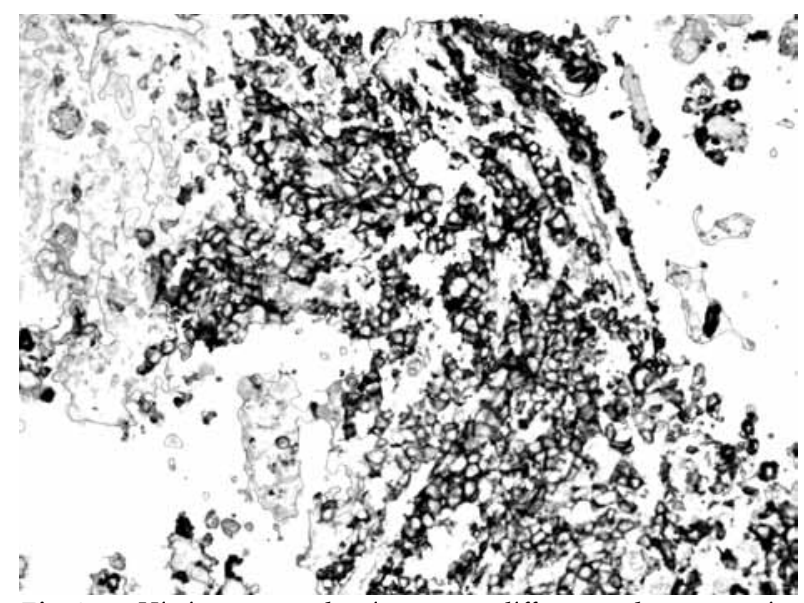

Fig. 3. Histiocytes are showing strong diffuse membranous staining with CD1a (CD1a $x 40)$. 
A spontaneous pneumothorax can be the presenting symptom. Pneumothoraces occur in $10 \%$ to $30 \%$ of patients. ${ }^{[3]}$ This patient developed spontaneous pneumothorax at hospital. More than $90 \%$ of cases of PLCH occur in smokers. Blood eosinophilia is unusual, but circulating immune complexes can be measured in serum in many patients with active disease, and their level reflects the degree of cellular reactivity in a lung biopsy. ${ }^{[4]}$

Typical findings on chest radiography include nodular or reticulonodular opacities most prominent in the middle and lower lung zones; later small cystic air spaces develop in the infiltrate producing a honeycomb pattern. ${ }^{[3]}$ High resolution computed tomography scan is highly distinctive, showing peribronchial cystic and nodular lesions predominantly in the mid- and upperlung zones.

Skin lesions are often the first manifestation of LCH. ${ }^{[5]}$ Erythematous papules, erosions, frank ulcers, nodular lesions, rashes, bruising of skin may be seen. Skin lesions which were present in this patient were diagnosed to be psoriatic lesions.

The most common finding in pulmonary function test is a reduction in the DLCO. ${ }^{[2]}$ Spirometry may show obstruction, but this may relate to underlying obstructive lung disease in cigarette smokers. Lung volumes are generally normal or increased. Restriction is seen in most interstitial lung diseases, increased lung volumes can be seen in patients with PLCH, lymphangioleiomyomatosis, tuberous sclerosis, hypersensitivity pneumonitis, and with concurrent emphysema. Later in the course of the disease, lung restriction may be present due to the fibrotic changes that can occur.

The diagnosis of PLCH can be confirmed by BAL, transbronchial biopsy, or surgical lung biopsy. The characteristic feature is aggregates of Langerhans cells, which are large histiocytes derived from dendritic cells. ${ }^{[6]}$ They stain positively for S-100 protein or OKT6 antigen. ${ }^{[7]}$ Other immunohistochemical stains for Langerhans cells include the monoclonal antibody MT-1 and human leukocyte antigen-DR. ${ }^{[2]}$ Electron microscopy demonstrates the Birbeck granule (pentolaminar body). The presence of more than 5\% Langerhans cells in BAL fluid by S-100 or OKT6 strongly supports the diagnosis. ${ }^{[2,6,7]}$ Transbronchial biopsies have a sensitivity of approximately $10 \%$ to $40 \%$. Surgical lung biopsies have the highest yield. ${ }^{[2]}$

The characteristic histologic findings of $\mathrm{PLCH}$ include the proliferation of Langerhans cells along the airways. ${ }^{[2]}$ Low-power microscopy typically shows nodular lesions that may have a "stellate" appearance. These nodules contain Langerhans cells, fibroblasts, lymphocytes, plasma cells, neutrophils, eosinophils, and macrophages. The stellate appearance is due to the central nodule with extensions along the alveolar walls.
Immunostaining of both BAL fluid and lung tissue is possible. Our patient was diagnosed with transbronchial biopsy.

The prognosis is generally better for focal disease limited to the lungs than for multifocal disease and bone involvement. Approximately 20\% of patients develop a lytic bone lesion. Bone scan was normal for this patient. Diabetes insipidus occurs in about $11 \%$ to $40 \%$ of patients. ${ }^{[8,9]}$ This patient also had diabetes insipidus which was treated with vasopressin. Regression of pulmonary symptoms and chest radiographic infiltrates may occur in $10 \%$ to $25 \%$ of patients within several months of diagnosis, although the disease does not disappear entirely without some residual symptoms.

The first-line therapy for PLCH is the avoidance of cigarette smoke. Corticosteroids have been used with positive results in some case series, but others have not shown a benefit. ${ }^{[2]}$ Chemotherapeutic agents such as cladribine, vinblastine, cytarabine, doxorubicin, methotrexate, cyclophosphamide and etoposide have been used in patients with progressive disease, but these agents remain experimental since data from prospective trials are lacking. In refractory disease, lung transplantation may be required. Unfortunately, recurrence after transplantation has been well documented .

Factors associated with poor prognosis include extremes of age, constitutional symptoms, decreased $\mathrm{FEV}_{1}$, decreased $\mathrm{FEV}_{1} / \mathrm{FVC}$ ratio, and reduced DLCO. ${ }^{[10]}$

In conclusion, if a patient with diffuse lung involvement is to be evaluated, three diseases; PLCH, tuberous sclerosis and lymphangiomyomatosis, with similar HRCT findings should be included in differential diagnosis. To reach the diagnosis, tissue biopsy should be performed and a less invasive diagnostic tool, transbronchial biopsy is one of the first of diagnostic tools to be attempted.

\section{REFERENCES}

1. Marcy TW, Reynolds HY. Pulmonary histiocytosis X. Lung 1985;163:129-50.

2. Green MB, Allen JN. Cough, dyspnea, and reticulonodular opacities in a 58-year-old smoker. Chest 2007;132:700-3.

3. Ryu JH, Colby TV, Hartman TE, Vassallo R. Smokingrelated interstitial lung diseases: a concise review. Eur Respir J 2001;17:122-32.

4. King TE Jr, Schwarz MI, Dreisin RE, Pratt DS, Theofilopoulos AN. Circulating immune complexes in pulmonary eosinophilic granuloma. Ann Intern Med 1979;91:397-9.

5. Egeler RM, D'Angio GJ. Langerhans cell histiocytosis. J Pediatr 1995;127:1-11.

6. Casolaro MA, Bernaudin JF, Saltini C, Ferrans VJ, Crystal RG. Accumulation of Langerhans' cells on the epithelial surface of the lower respiratory tract in normal subjects in association with cigarette smoking. Am Rev Respir Dis 1988;137:406-11.

7. Idiopathic intertitial pneumonia and other diffuse parenchymal lung diseases. In: Travis WD, Colby TV, Koss MN, 
Rosado-de-Cristenson MI, Müller NL, King TF, editors. Non-neoplastic disorders of the lower respiratory tract. 1st ed. Washington: American Registry of Pathology; 2002. p. 49-232.

8. Campos MK, Viana MB, de Oliveira BM, Ribeiro DD, Silva CM. Langerhans cell histiocytosis: a 16-year experience. J
Pediatr 2007;83:79-86.

9. Aricò M, Egeler RM. Clinical aspects of Langerhans cell histiocytosis. Hematol Oncol Clin North Am 1998;12:247-58.

10. Vassallo R, Ryu JH, Schroeder DR, Decker PA, Limper AH. Clinical outcomes of pulmonary Langerhans'-cell histiocytosis in adults. N Engl J Med 2002;346:484-90. 